\title{
Effect of Spontaneous Lactic Acid Fermentation on Physico-Chemical Properties of Sweet Potato Flour
}

\author{
NETI YULIANA*, SITI NURDJANAH, RIBUT SUGIHARTO, AND DEARY AMETHY \\ Department of Agricultural Product Technology (THP), Agriculture Faculty, Universitas Lampung, \\ Jalan Sumantri Brojonegoro No 1, Bandar Lampung 35145, Indonesia
}

\begin{abstract}
Native sweet potato flour is usually has low whiteness index and limited application to food systems due to its inherent functional properties. Therefore, it needs modification process to improve this property. In this study, sweet potatoes cubes were lactic spontaneously fermented for $120 \mathrm{~h}$ before being processed to flour to modify its properties. Selected physico-chemical properties of flour were then determined and compared with the control (without fermentation). The results showed that lactic acid fermentation significantly caused more changes on flour properties. The lactic acid fermentation caused an alteration in the starch granules as evident by Scanning Electron Microscopy. When compared to the control flour, spontaneous fermented flour had lower solubility, higher swelling power, and paste viscosity. The results suggested lactic spontaneous fermentation within $120 \mathrm{~h}$ period of time could provide a greater extent of flour modification.
\end{abstract}

Key words: modified sweet potato flour, spontaneous lactic acid fermentation

Tepung ubi jalar biasanya mempunyai indeks putih yang rendah dan sifat fungsional alami yang menyebabkan keterbatasan aplikasi dalam sistem pangan. Dengan demikian tepung ubi jalar perlu dimodifikasi untuk memperbaiki sifat-sifat fungsionalnya. Pada penelitian ini, potongan ubi jalar difermentasi laktat secara spontan selama 120 hari sebelum diproses menjadi tepung untuk memperbaiki sifat fungsionalnya. Sifat fisiko kimia terpilih kemudian diukur dan dibandingkan dengan tepung hasil perlakuan yang tidak difermentasi (kontrol). Hasil penelitian menunjukkan bahwa fermentasi asam laktat secara nyata menyebabkan perubahan sifat-sifat tepung. Fermentasi menyebabkan perubahan granula pati seperti yang ditunjukkan pada gambar hasil Scanning Electron Microscopy. Jika dibandingkan dengan kontrol, tepung hasil fermentasi mempunyai kelarutan yang lebih rendah, kemampuan pembengkakan granula, dan viskositas pasta yang lebih tinggi. Hasil ini mengindikasikan bahwa fermentasi secara spontan selama 120 jam dapat menghasilkan proses yang berdampak besar terhadap modifikasi tepung.

Kata-kata kunci: fermentasi asam laktat spontan, tepung ubi jalar termodifikasi

Sweet potato flour is generally produced conventionally by drying of sliced peeled tubers followed by grinding and sieving to pass different mesh size. This process has disadvantages such as limited use in application, primarily in food system, and low whiteness index. Sweet potato flour has viscosity profile, rehydration, and solubility that are less favorable than those of wheat flour. In addition native flour did not show any thermo pasting behavior when subjecting to amylograph brabender (Yuliana and Nurdjanah 2013). The native sweet potatoes flour has low viscosity that makes it just useful for the food that require lower viscosity (Aprianita et al. 2009)

In this research we tried to improve or modify sweet potato flour properties trough spontaneous fermentation of the fresh tuber, so that the flour is whiter and has broader application in various food products. Previous studies showed lactic fermentation

*Corresponding author; Phone/Fax: +67-721-781498, Email:yuliana_thp@unila.ac.id has been implemented in some flour and starch production, such as in the production of sweet potato starch (Deng et al. 2013), sour cassava flour (Putri et al. 2011), cocoyam flour (Oke and Bolarinwa 2012) and rice flour (Lu et al. 2005). Mutwiri (2007) and Kasim (2012) worked on naturally fermented sweet potato flour that was prepared by drying a fresh sweet potato pulp before fermenta sausages filling (Mutwiri 2007). In African countries, lactic acid fermentation has been practiced to improve nutritional value and taste. For examples, amylolytic LAB are mainly distributed in directly Nigerian fermented meals (Sanni et al. 2002), and traditional African fermented sorghum (Yousif et al.2010).

Lactic acid bacteria as dominant organisms in food fermentations will convert free sugars to lactic acid, produce amylolytic enzymes that degrade starch granules and hydrolyze the short chain amilose and amylopectin in amorphous region of starch granules. The degradation of starch granule by lactic acid during fermentation could change the porosity and surface 
area of the granule and would modify the properties of flour. Information about these physicochemical properties is important to determine the usability of fermented sweet potatoes flour on various food products.

Beside amylolitic enzymes, lactic acid bacteria also produce proteolitic enzymes as well as organic acids which degrade protein and inactivate polyphenol oxidase in sweet potatoes. Lower protein content, inactivation of polyphenol oxidase together with low free sugar content as a result of the conversion of free sugar to lactic acid in fermented sweet potatoes flour may reduce the non enzymatic browning during flour drying. Thus, it will result in increasing whiteness of sweet potatoes flour.

\section{MATERIALS AND METHODS}

Sweet Potato Fermentation. White-fleshed sweet potato samples were obtained from Pasar Gintung, a local market at Bandar Lampung, Province of Lampung-Indonesia. The sweet potatoes were washed, peeled, and cut into cubes $\left(1 \times 1 \times 1 \mathrm{~cm}^{3}\right)$. The potato cubes $(40 \mathrm{~g})$ were put into a $150 \mathrm{~mL}$-fermenting container, then it was made up to $150 \mathrm{~mL}$ volume with the $3 \%$ brine solution. The fermenting containers containing the samples were pasteurized using a microwave oven (Sharp) at high level setting for $10 \mathrm{~min}$ to reach temperature around $72-73{ }^{\circ} \mathrm{C}$, and then they were left at room temperature to cool. The fermentation was conducted at room temperature $\left(30^{\circ} \mathrm{C}\right)$ for $120 \mathrm{~h}$ to let them reach completely fermentation. This was indicated by drop in $\mathrm{pH}$ to 4.0 and unique acid aroma of fermented sweet potatoes cube as described in previously author (Yuliana et al. 2010). Microbial growth during fermentation was evaluated by enumerating total of lactic acid bacteria (LAB) using total plate count method. Appropriate dilutions were placed on duplicate plates of MRS medium (Oxoid) with $0.1 \%(\mathrm{w} / \mathrm{v}) \mathrm{CaCO}_{3}$. The cultures were incubated at $30{ }^{\circ} \mathrm{C}$ for $48 \mathrm{~h}$. LAB was identified by the presence of clear zones around the colonies; The experiment was designed in three replicates. The control (non fermented flour) was prepared by drying fresh cubes of sweet potatoes followed by milling and sieving.

Sweet Potatoes Flour Production. After fermentation has been completed, the cubes were washed with running tap water until the water runs clear and then drained. The fermented cubes of sweet potatoes were dried in an oven at $65^{\circ} \mathrm{C}$ overnight until the moisture content reaches approximately $12 \%$. These dry fermented cubes were then ground into flour to pass through an $80 \mu \mathrm{m}$ mesh sieve size. The same procedure was applied to dry cubes from fresh sweet potatoes without fermentation to make control sweet potatoes flour. The flour was packed in polythene bags and stored at ambient temperature of around $25 \pm 2{ }^{\circ} \mathrm{C}$ for further analysis.

pH and TA. Sweet potatoes flour samples $(5 \mathrm{~g})$ were weighed in triplicate into a beaker, mixed with 20 $\mathrm{ml}$ of distilled water. The resulting suspension stirred for $5 \mathrm{~min}$ and left to settle for $10 \mathrm{~min}$. The $\mathrm{pH}$ of the water phase was measured using a calibrated $\mathrm{pH}$ meter (AACC, 2000). The TA was measured using titration method with phenolpthalein as indicator of end titration.

Morphology of Sweet Potatoes Starch Granules. The morphology of starch granules was evaluated by scanning electron microscope (JSM-6510LV SEM). Flour samples were suspended in 95\% ethanol and mounted on circular aluminium stubs with doublesided sticky tape. The flour granules were evenly distributed on the surface of the tape, and the ethanol was allowed to evaporate. The samples were then coated with $12 \mathrm{~nm}$ gold, examined and photographed at an accelerating voltage of $15 \mathrm{kv}$ with a magnification of $2000 \times$.

Swelling power and solubility. Swelling power and water solubility index (WSI) determinations were carried out in the temperature range $60-80{ }^{\circ} \mathrm{C}$ at $10{ }^{\circ} \mathrm{C}$ intervals. Briefly, $0.5 \%$ flour suspensions were prepared in $15 \mathrm{~mL}$ tubes and heated in a water bath at 60,70 , and $80^{\circ} \mathrm{C}$ for $30 \mathrm{~min}$ with constant agitation to avoid sedimentation. This was followed by centrifugation at $1000 \times \mathrm{g}$ for $15 \mathrm{~min}$ at $20{ }^{\circ} \mathrm{C}$. The sediment fraction was weighed and its mass related to the mass of dry starch was expressed as swelling power $(\mathrm{w} / \mathrm{w})$. The solubility was reported as the ratio of the weight of total soluble starch to the weight of dried sample.

Pasting properties of flour. The pasting properties of the flour were evaluated by using a Micro Visco Amylo Graph (Brabender). Flour suspensions $(10 \%, \mathrm{w} / \mathrm{w})$ were equilibrated at $30{ }^{\circ} \mathrm{C}$ for $1 \mathrm{~min}$, heated at $95^{\circ} \mathrm{C}$ for $5.5 \mathrm{~min}$, at a rate of $6{ }^{\circ} \mathrm{C} \mathrm{min}^{-1}$, held at $95^{\circ} \mathrm{C}$ for $20 \mathrm{~min}$, cooled down to $50^{\circ} \mathrm{C}$ at a rate of 6 ${ }^{\circ} \mathrm{C} \mathrm{min}{ }^{-1}$ and finally held at $50{ }^{\circ} \mathrm{C}$ for $20 \mathrm{~min}$. It was a programmed heating and cooling cycle. Parameters recorded were pasting temperature (PT), peak viscosity (PV), minimum viscosity (MV), or trough viscosity (TV), final viscosity (FV), and peak time (PTime). Breakdown viscosity (BV) was calculated as 
the difference between PV minus MV, while total setback viscosity (TSV) was determined as the FV minus MV. All determinations were performed in duplicate.

Flour Whiteness. Sweet potatoes flour whiteness was determined using a Powder Whiteness Tester Model C 100, Kett Electric Laboratory. A 25 g sample of flour was weighted and put in the sample container. The top of container was then closed and container was inserted into the sample holder in the system. The values of whiteness were the average from three measurements.

\section{RESULTS}

pH and TA of Flour. Changes in $\mathrm{pH}$ and titratable acidity (TA) of flour are shown in Table 1 and Fig 1. Fermentation was found to cause a gradual reduction in a pH from 6.49 to 4.5. Concomitant with the drop in $\mathrm{pH}$, there was a rise in TA of SP flours throughout the fermentation process from $0.02 \%$ to $1.68 \%$.

Flour Whiteness. Fermentation improved the whiteness of SP flour (Fig 2). Fermented flour was observed to have higher whiteness index compared to that in control.

Solubility. Sweet potato flour is difference in solubilitty. In general, fermented flour has lower solubility in spite of the temperature over 60 to $80^{\circ} \mathrm{C}$.

Swelling Power. Any significant change in swelling power of SP flour, as shown in Fig 4. At $60^{\circ} \mathrm{C}$ the swelling power of both treatments was very low, and this value increased when the heating reached 70 ${ }^{\circ} \mathrm{C}$. The granules of control sweet potato flour swelled at a lower temperature $\left(\sim 73^{\circ} \mathrm{C}\right)$ in comparison to those of spontaneous sweet potato flour, which swelled at $\sim 75^{\circ} \mathrm{C}$. The swelling power of control sweet potatoes flours increased steadily with a temperature rise from 60 to $80{ }^{\circ} \mathrm{C}$, as opposed to fermented sweet potato flour with a rapid change of swelling power in this temperature region. At $80^{\circ} \mathrm{C}$, the swelling power of the fermented sweet potato flour was greater than that of control flours.

Pasting Properties. Table 2 demonstrates the viscosity profile of different flour. The fermented flour samples had the higher maximum viscosity, break down and set back than those of control. However, the control had the higher peak time (10 min), and pasting temperature $\left(93.87{ }^{\circ} \mathrm{C}\right)$ which may indicate different structural rigidity in comparison to fermented sweet potato flour.

Morphology of Granule. Fig 5 shows mild superficial corrosions on some starch granules by

Table $1 \mathrm{pH}$ and titratable acidity (TA) at control (fresh SP) and spontaneously fermented SP flour

\begin{tabular}{lll}
\hline Treatment & \multicolumn{1}{c}{ TA $(\%)$} & $\mathrm{pH}$ \\
\hline Control & $0.02 \pm 0.005$ & $6.49 \pm 0.63$ \\
Spontaneous & $1.68 \pm 0.16$ & $4.5 \pm 0.61$ \\
\hline
\end{tabular}
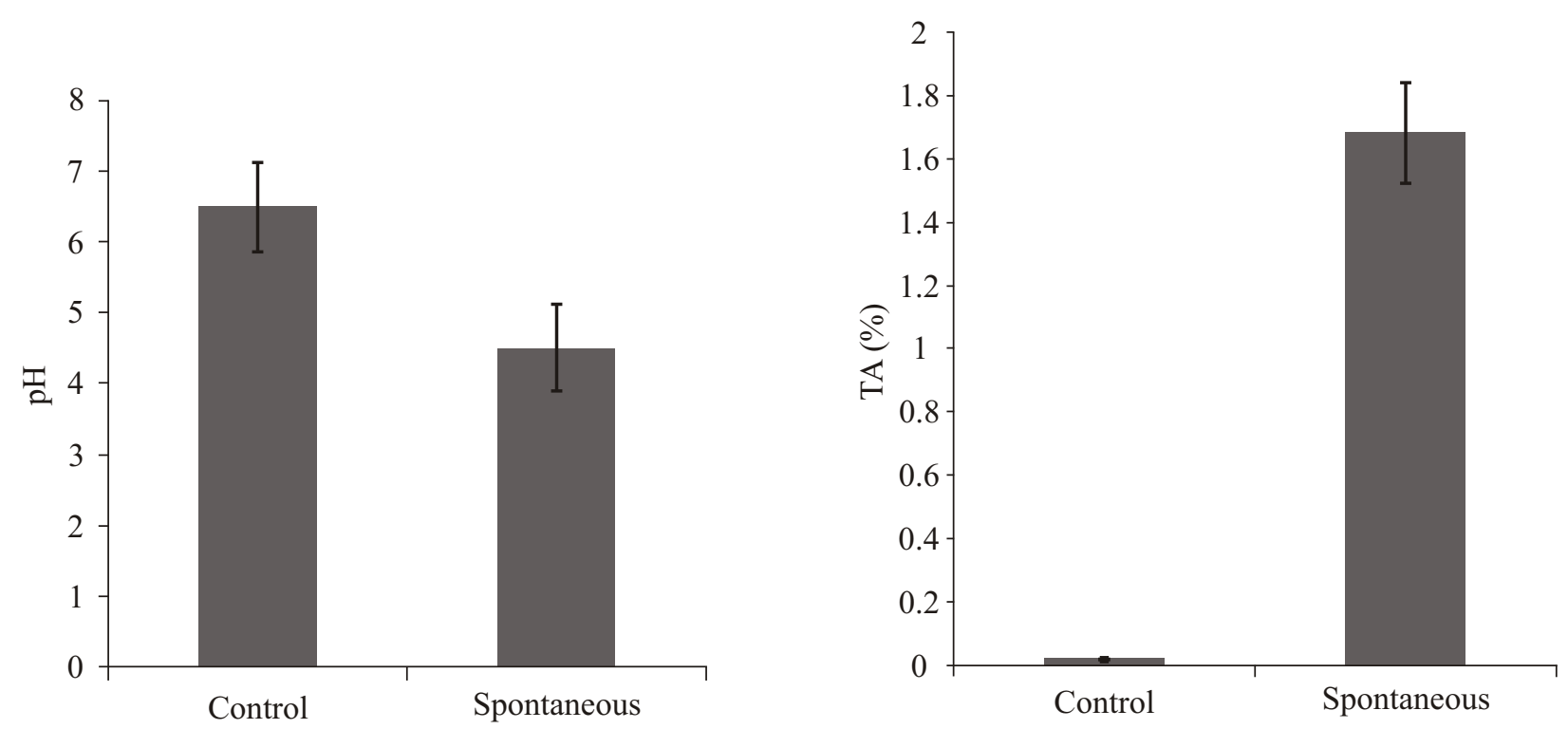

Fig $1 \mathrm{pH}$ and titratable acidity (TA) of control (fresh SP) and spontaneous fermented SP flour. 


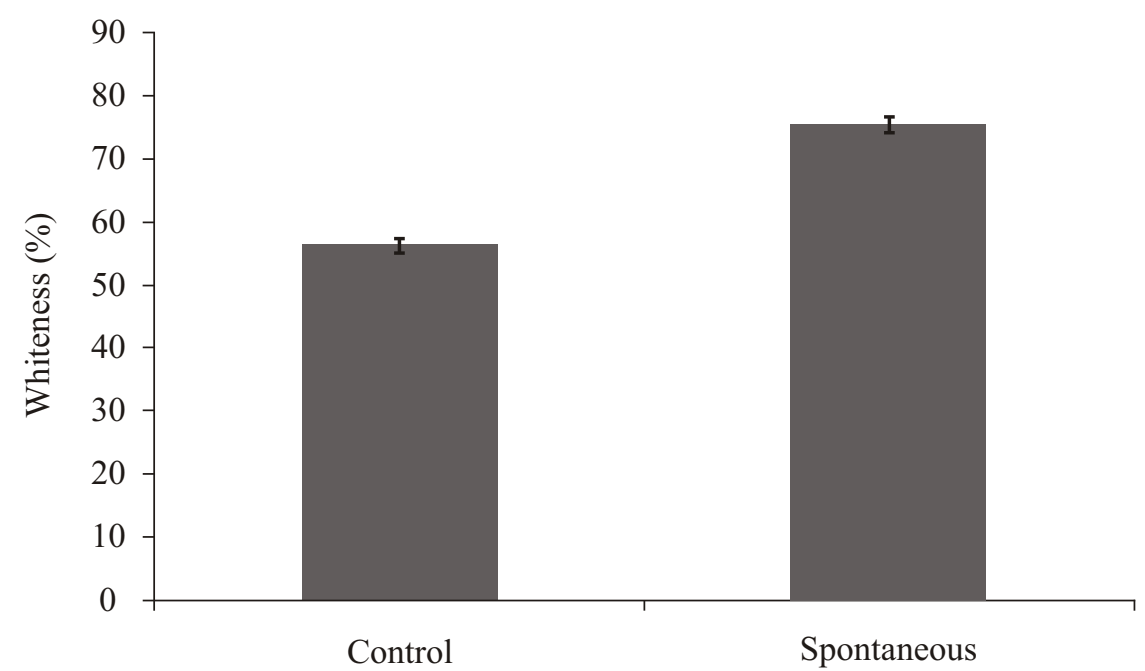

Fig 2 Whiteness (\%) of control and spontaneous fermented SP flour.

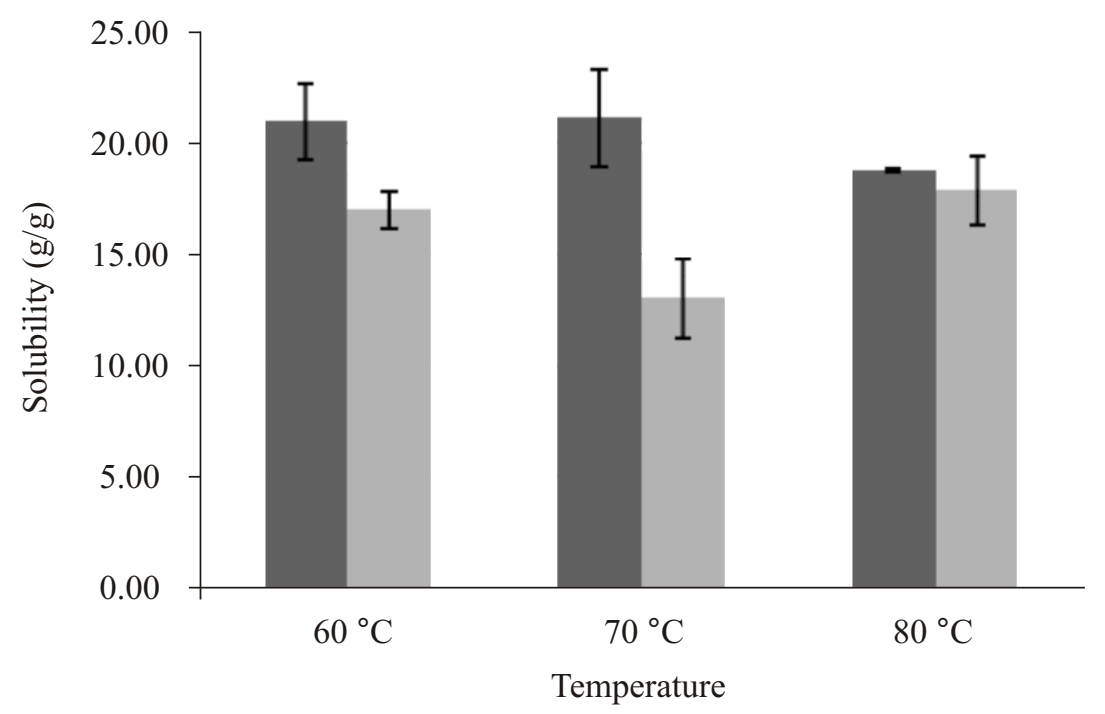

Fig 3 Solubility of control (fresh) and spontaneous fermented SP flour. $\square$ : control and $\square$ : fermented.

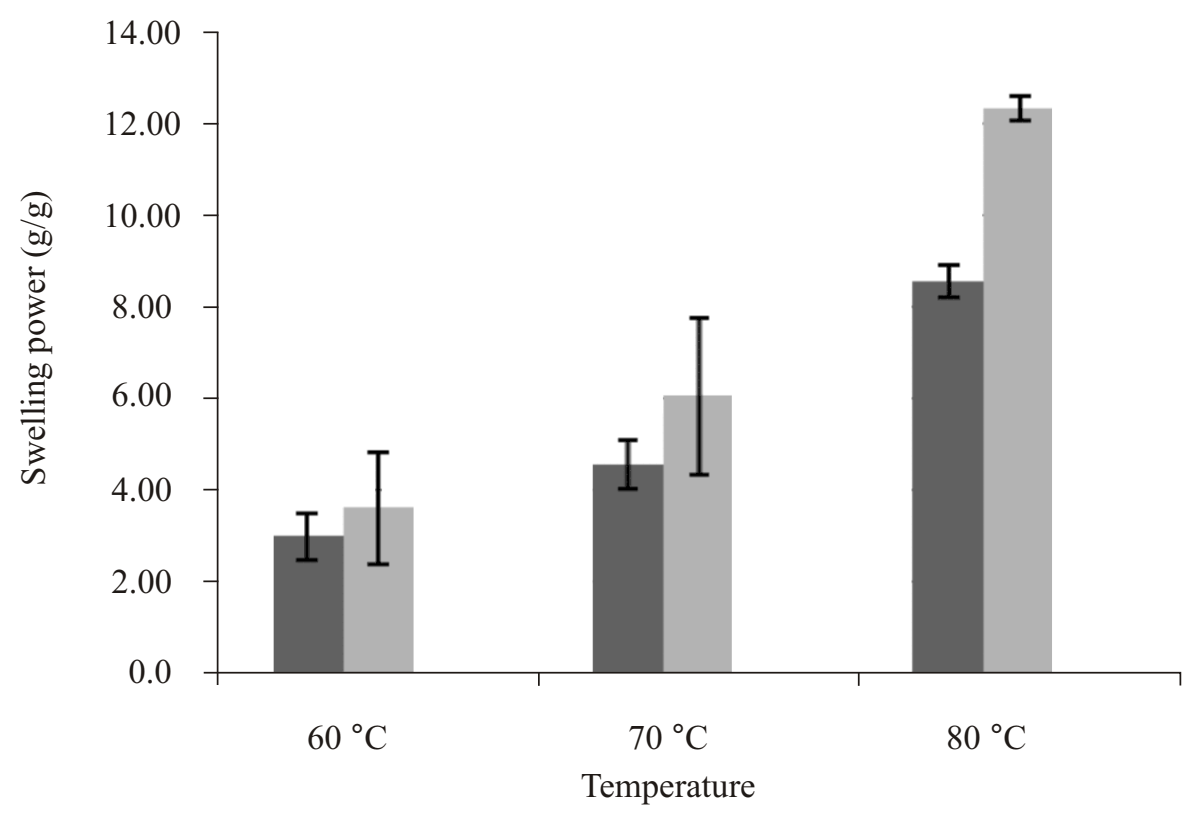

Fig 4 Swelling power of control (fresh) and spontaneous fermented SP flour. $\square$ : control and $\square:$ fermented. 
fermentation. The spontaneous fermented samples were much smoother surface angle, etched and had very shallow pits but the control samples had no pits when examined using scanning electron microscopy.

\section{DISCUSSION}

Fermentation was found to cause a gradual reduction in a $\mathrm{pH}$. This result is in agreement with Yuliana et al. (2013) and Adebayo-Oyetoro et al. (2012) who reported that lactic acid fermentation causes a rapid drop in $\mathrm{pH}$ as in sweet potatoes cube and cassava tubes fermentation. Spontaneous fermentation of carbohydrate-rich biomass such as SP, cassava, sorghum, and caper berries, is mainly lactic acid fermentation (Yuliana et al. 2013; Kakou et al. 2010; Yousif et al. 2010; Pulido et al. 2005). The $\mathrm{pH}$ of the fermented SP flour is lowered due to the production of organic acids by lactic acid bacteria. Total LAB grew during fermentation in this research was around 0.619 at day 1 to $7.803(\log 10 \mathrm{CFU})$ at day $5(120 \mathrm{~h})$. This could explain the apparent increase in lactic acid towards the end of fermentation accompanied by decrease in $\mathrm{pH}$.

Fermentation was observed to improve the whiteness index of SP flour (Fig 2). This can be ascribed to flour purification by spontaneous fermentation and the decrease of ash, protein and sugar content. It is generally accepted that the ash content, protein and free sugar are factor affecting the whiteness of flours such as those from cassava and rice (Sobowale 2007; Lu et al. 2005). During fermentation, bacteria would produce proteolityc which degraded protein in sweet potatoes, convert free sugar to lactic acid thus the content of protein and free sugar in fermented flour was lower than those at control. A higher protein and free sugar content in control flour may cause the non enzymatic browning during flour drying which result in darker color, thus

Table 2 Pasting properties of control and fermented SP flour

\begin{tabular}{lcc}
\hline Pasting properties & Control & Fermented \\
\hline Beginning of gelatinization & $73.78 \pm 0.65$ & $75.38 \pm 0.83$ \\
Maximum viscosity (BU) & $215.00 \pm 4.16$ & $473.50 \pm 89.41$ \\
Peak time & $10 \mathrm{~min}$ & $7.5 \mathrm{~min}$ \\
Temperature at max viscosity & $93.87 \pm 0.69$ & $84.30 \pm 2.63$ \\
Breakdown (BU) & $21.50 \pm 10.47$ & $216.00 \pm 6.98$ \\
Setback (BU) & $62.25 \pm 5.50$ & $156.50 \pm 20.14$ \\
\hline
\end{tabular}

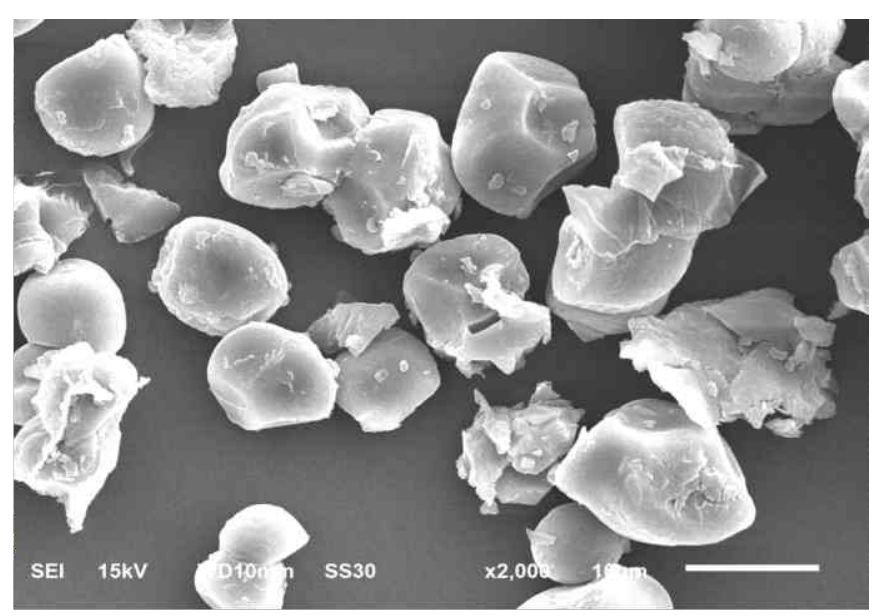

A

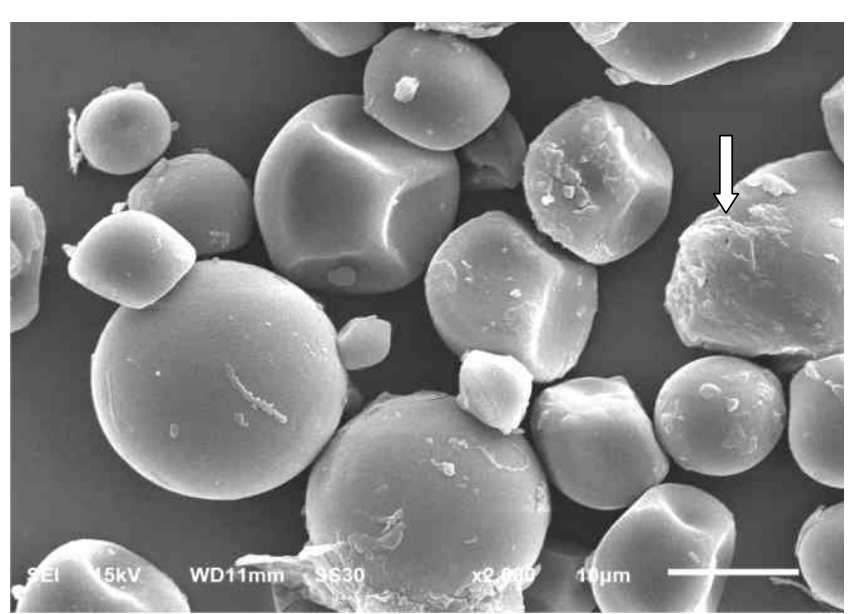

B

Fig 5 Scanning electron micrographs of control and fermented SP flours (15 kV, 2000$)$. The arrows show etches on the starch granules. A: control flour and B: spontaneous fermented flour. 
reducing whiteness of flour.

Fermentation was found to make difference in solubility of sweet potato flour as shown in Fig 3. This could be caused by starch structural differences, such as chain length distribution and granular size. BelloPerez et al. (2000) reported that the distributions of chain length in the starches cause differences in solubility, and Tian et al. (1991) stated that granular size also affects solubility of the starches where the smaller the granule size, the higher the starch solubility. In this study it was revealed that based on SEM analysis, the granular size of the fermented flour was bigger than that of control.

Fermentation caused any significant change in swelling power of SP flour. There was difference start in rapid swell beetween the granules of control sweet potato flour and those of spontaneous sweet potato flour. The starch granules start to swell rapidly only after the temperature reached the onset of the gelatinization temperature (Jacguier et al.2006). The onset gelatinization temperature of control sweet potatoes flour was $73.78 \pm 0.65{ }^{\circ} \mathrm{C}$, and those of spontaneous sweet potatoes flour was $75.38 \pm 0.83{ }^{\circ} \mathrm{C}$ as determined by micro visco amylograph, corresponded to the start of the rapid increase of swelling power of these flours.

There was also difference pattern in rapid change of swelling power between control and fermented SP flour. The swelling power of flour samples is often related to their protein and starch contents (Woolfe 1992). During fermentation, bacteria would produce proteolytic enzymes which degrade protein in sweet potatoes, thus the content of protein in fermented flour was lower than those at control. A higher protein content in control flour may cause the starch granules to be embedded within a stiff protein matrix, which subsequently limits the access of the starch to water and restricts the swelling power. Furthermore, during fermentation, lactic acid bacteria would produce amylase that hydrolyzes amylose thus reduce amylose content. Lower amylose content would increase the swelling factor of starch (Tester and Morisson 1990). According to Leach et al. (1959), the major factor that controls the swelling behavior of a starch is the strength and character of the micellar network within the granule. The control flour samples may have a greater structural rigidity in comparison to fermented sweet potato flour. LAB is known to produce amylases, and when starch were treated with amylases there was an initial attack on the amorphous regions of the starch granule. French (1984) observed that intercrystalline amorphous areas in the starch granule are relatively susceptible to hydrolytic agents such as various enzyme and acids . Beside producing enzyme, LAB also produced organic acids, mainly lactic acid during fermentation.

The pasting behavior of the control and spontaneous SP flour was studied by observing changes in the viscosity of a flour system based on the rheological principals. During heating in water, starch of flour began to gelatinize as the granules became swollen and partially solubilized, contributing to a viscous starch paste. The control flour samples, had the higher peak time (Table 2), which may indicate a greater structural rigidity in comparison to fermented sweet potato flour. This structural rigidity was also observed from the lower swelling power as discussed previously.

The control sweet potato flour had higher (93.87 ${ }^{\circ} \mathrm{C}$ ) pasting temperature than the fermented flour having the lower $\left(84.30^{\circ} \mathrm{C}\right)$. Also control sweet potato flour had lower peak viscosity as opposed to the fermented SP flour (Table 2). This observation might have been influenced by lower rigidity of starch granules in fermented sweet potato, which in turn caused instability and consequently disruption upon the heating and stirring treatment (Leon et al.2006).

On the other hand, the higher peak viscosity of the spontaneous fermented flour compared to control flour samples could be due to the increase of granule size (Fig 1A), which also led to higher swelling power (Fig 2A) and subsequently higher viscosity. The high viscosity of fermented SP would make them very useful in food applications where high thickening power is required. However, the viscosity of this flour decreased substantially afterwards. This phenomenon is probably likely due to lower protein content and free leaching of amylose and amylopectin from the granules (Leon et al. 2006).

Fermented flour also showed a retrogradation tendency, indicated by the rise of viscosity during cooling period as shown in its setback value. Setback is a measure of recrystallization of gelatinizatied starch during cooling or measurement of retrogradation. The spontaneous fermented SP flour had setback value higher than control flour. A higher retrogradation tendency of fermented SP makes it suitable for use in jelly foods and noodle. A good quality of noodle is thought to result from the pasted starch that exhibit a high set back value on cooling (Lii and Chang 1981).

Breakdown viscosity measure of the vulnerability or susceptibility of the cooked starch to disintegration. 
The higher the breakdown in viscosity, the lower the ability of the starch sample, to withstand heating and shear stress during cooking (Adebowale et al. 2005). Therefore fermented SP flour might be less able to withstand more heating and shear stress compared to control flour because of their higher breakdown value. Other modified technique fermentation was needed to reduce the breakdown value of this flour. The stability of fermented flour against heat and mechanical treatment would also be useful in many other food applications.

In regard to morphology of granule, there was presence of the pits and smoother surface angle in the starch granules seems to indicate some breakdown of the starch. We presume that they might be caused by the digestion of some starch by lactic acid bacteria. In addition, cell wall material on control flour still attached to the starch granules in control flour, while those has been released in fermented flour. The size of starch granules in fermented flour become bigger than those in control. Fermentation may thus change the amorphous region of the starch granule, size of the granule as well as the chemical components and thereby modify both physical properties of SP flour and its rheological characteristics.

Based on the systematic analysis of the physical properties of SP flour and its rheological characteristics, it can be concluded that lactic spontaneous fermentation had great effect on starch crystalline and the amorphous region. The results revealed that fermentation may change the amorphous region of the starch granule, size of granules, as well as the chemical components and it may modify the physical and pasting properties of SP flour. Therefore, fermented SP flour is easily swollen and soluble. Further research work is needed to apply this fermented flour for making product such as noodle that is suitable from these change properties.

\section{REFERENCES}

AACC, American Association of Cereal Chemists. 2000. Approved methods of the AACC. Methods 02-52

Adebayo-Oyetoro AO, Olatidoye OP, Ogundipe OO, Balogun IO, Apara TO. 2012. Effect of local cassava fermentation methods on functional pasting and sensory properties of lafun. Continental J Agricl Sci. $6(2): 1-8$.

Aprianita A, Purwandari U, Watson B, Vasiljevic T. 2009. Physico-chemical properties of flours and starches from selected commercial tubers available in Australia. Int Food Res J. 16:507-520
Bello-Pérez LA, Contreras-Ramos SM, Jimenez-Aparicio A, Paredes-Lopez O. 2000. Acetylation and characterization of banana (Musa paradisiaca) starch. Acta Cientifica Venezuela 51:143-149.

Deng F-M, Mu T-M,Zhang M, Abegeunde OK. 2013. Composition, structure and physicochemical properties of sweet potato starches isolated by sour liquid processing and centrifugation. Starch/Starke 65(12):162-171.

Leach HW, McCowen LD, Schoch TJ. 1959. Structure of the starch granule. 1. Swelling and solubility patterns of various starches. Cereal Chem. 36:534-544

Lii C-Y, Chang S-M. 1981. Characterization of red bean starch and its noodle quality. J Food Sci. 46(1):78-81. doi:10.1111/j.1365-2621.1981.tb14535.x.

Leon AE, Barrera GN, Perez GT, Ribotta PD, Rosell CM. 2006. Effect of damaged starch levels on flour-thermal behaviour and bread staling. Eur Food Res Technol. 224(2):187-192. doi:10.1007/s00217-006-0297-X.

Lu Z-H, Li L-T, Min W-H, Wang F, Tatsumi E. 2005.The effects of natural fermentation on the physical properties of rice flour and the rheological characteristics of rice noodles. Int J Food Sci Technol. 40(9):985-992. doi:10.1111/j.1365-2621.2005.01032.x.

French, D. 1984. Organization of starch granules in starch:chemistry and technology. Eds RL Whistler, EF Paschal, and JN Bemiller 2rd ed, Academic Press, London:184-247.

Jacguier JC, KaarA, Lyng JG, Morgan DJ, McKenna BM. 2006. Influence of granule size on the flow behaviour of heated rice starch dispersions in excess water. Carbohydrate Polymers 66(4):425-434. doi:10.1016/j. carbpol.2006.03.029.

Kakou CA, Guehi ST, Olo K, Kouame FA, Nevry RK Koussemon CM. 2010. Biochemical and microbial changes during traditional spontaneous lactic acid fermentation process using two varieties of cassava for production of a "Alladjan" starter. Int Food Res J. 17:563-573.

Kassim, SM. July, 2012. Effect of fermentation period on functional and pasting properties of sweet potato flour "Elubo". Food Sci and Technol, Federal University of Agriculture, Abeokuta.

Mutwiri TW. 2007. Textural characteristics of lactic fermented sweet potato and its performance as sausage. filler http:/erepository.uonbi.ac.ke:8080/xmlui/handle $/ 123456789 / 19104$.

Oke MO, Bolarinwa IF. 2012. Effect of Fermentation on physicochemical properties and oxalate content of cocoyam (Colocasia esculenta) flour, ISRN Agronomy Volume 2012:1-4.

Pulido RP, Omar NB, Abriouel H, Lo 'pez RL, Canamero MM, Gálvez A. 2005. Microbiological study of lactic acid fermentation of caper berries by molecular and culture-dependent methods. Applied and Environ Microbiol. 71(12):7872-7879 doi:10.1128/AEM.71.12. 7872-7879.2005.

Putri WDR, Haryadi DW, Marseno, Cahyanto MN. 2011. 
Effect of biodegradation by lactic acid bacteria on physical properties of cassava starch. Int Food Res J. 18(3):1149-1154

Sanni A, Morlon-Guyot J, Guyot JP. 2002. New efficient amylase-producing strains of Lactobacillus plantarum and L. fermentum isolated from different Nigerian traditional fermented foods. Int J Food Microbiol. 72(12):53-62. doi:10.1016/S0168-1605(01)00607-9.

ShimelisE, Meaza M, Rakishit S. 2006. Physicochemical properties, pasting behaviour and functional characteristics of flours and starches from improved bean (Phaseolus vulgaris L) varieties grown in East African. CIGR E- Journals 8:1-18.

Sobowale AO, Olurin TO, Oyewole OB. 2007. Effect of lactic acid bacteria starter culture fermentation of cassava on chemical and sensory characteristics of fufu flour. Afr J Biotechnol. 16(16):1954-1958.

Tester RF, Morrison WR. 1990. Swelling and gelatinization of cereal starches. I. Effect of amylopectin, amylose and lipids. Cereal Chem. 67:551-559.

Tian SJ, Rickard JE, Blanshard JM. 1991. Physicochemical properties of sweet potato starch. J Sci Food Agri. 57(4):451-491. doi:10.1002/jsfa.2740570402.
Yousif NMK, Huch M, Schuster T, Cho G- S , Dirar HA, Holzapfel WH, Franz MAP. 2010. Diversity of lactic acid bacteria from Hussuwa, a traditional African fermented sorghum food. Food Microbiol. 27(6):757768. doi:10.1016/j.fm.2010.03.012.

Yuliana N, Nurdjanah S. 2013. Development of sweet potatoes pickle as modified flour: Effort to balance the need of wheat. Research Report. Universitas Lampung.

Yuliana N, Nurdjanah S. 2009. Sensory properties of spontaneously fermented purple sweet potato pickle at various salt concentration. Jurnal Teknologi dan Industri Hasil Pertanian 14:120-128.

Yuliana N, Nurdjanah S, Margareta M. 2013. The Effect of a mixed-starter culture of lactic acid bacteria on the characteristics of pickled orange-fleshed sweet potato (Ipomoea batatas L.). Microbiol Indones. 7(1):1-8. doi:10.5454/mi.7.1.1.

Yuliana N, Nurdjanah S, Ocatrini ZH. 2010. Some biochemical and total lactic acid bacteria changes during natural fermentatioan of the purple sweet potatoes. Proceeding International Seminar on Holticulture to support Food Security: B209-B214. 